\title{
The Only thing that Fans want
}

\author{
Manh-Toan Ho \\ Phenikaa University \\ Hanoi, June 1, 2021
}

Recently, the public has been outraged toward a new trend: homemade adult content selling on various online platforms $[1,2]$. Indeed, this is a common reaction from Vietnamese media. In a country that is distinctly Confucianism $[3,4]$, adult contents are taboo and forbidden. A recent study from Do et al. [5] suggested that parents consider children to be rotten if they exert some sexual behaviors. Consequently, the parents find a way to control the teenagers to prevent them from these rotten behaviors.

Despite these attitudes, sexual relations were perceived differently throughout Vietnam history. Researchers have found evidence to suggest sexual relations were perceived as a natural activity in folk culture, and Vietnamese people have specific rituals to celebrate these activities [6]. However, over the course of history, Confucian ethics and other factors have made the attitudes toward sex also become more restrictive $[6,7]$.

Thus, the proactive attitude of the young generation toward sexual relations, to the point that they are willing to sell and make money off their own supposedly private activities, is quite fascinating. Social sciences and humanities researchers should take a look at the phenomenon.

This short paper offers a viable pathway to explain the thought process of individuals who are engaging in creating adult content. The pathway is supported by the mindsponge (MSp) mechanism, popularized by Vuong Quan Hoang in his seminal papers in 2015 and 2016 [8,9]. Aside from that, cultural additivity (CA) [3] is also used to explain the simultaneous existence of contradicting values in a belief system.

Firstly, we can safely assume that the core mindset of Vietnamese people is characterized by Vietnamese culture. As suggested above, researchers have agreed that Vietnamese people are restrictive and overprotective regarding sexual issues [5-7]. The value has been the core mindset of Vietnamese people for several generations. That is why parents are overprotective of their children when it comes to sex [5]. However, several external factors have introduced new values: the openness after Đôi mói, the increase of wealth, the Internet, the social media, the inflow of popular culture, the newfound attention to sexual education. Each element contributes significantly to the change in the psyche of the society that takes several generations to express itself more clearly. The Internet makes us more open to different ideas. Social media allow us to express ourselves in different ways. Here, the core mindset is supposed to filter against new values. However, the role of cultural additivity is crucial because it allows the new 
values to reside in the comfort zone and then slowly enter the core mindset. Moreover, the monetization of one's body and sexual activities also suggests they accept the attention and material wealth that it brings.

Indeed, the above analysis is somewhat speculative, premature, and leaves room for future development [10]. I believe that we need a deeper understanding of this phenomenon, rather than merely label children engaged in these activities as spoil. This type of research will need us to be sensitive with our thinking. We should be proactive in understanding the thought process rather than merely finding evidence of spoiled behaviors [11]. Finally, the quality of the research should be of the best quality because mishandling of the material can be devastating to the research subject [12].

\section{References}

[1] Kid, D., Hình, V., \& Toran. (2021). Đột nhập thế giới "nội dung 18 " tự sản xuất của giới trẻ Việt: Quy mô ngày càng bành trướng, nhiều trò biến thái đến rùng mình. Kenh14. Retrieved from https://kenh14.vn/thoi-cua-noi-dung-18-tra-phi20210411144858942.chn

[2] Kid, D., Hình, V., \& Toran. (2021). Đột nhập thế giới "nội dung 18 " tự sản xuất của giới trẻ Việt: Quy mô ngày càng bành trướng, nhiều trò biến thái đến rùng mình. Doanh nghiệp và Tiếp thị. Retrieved from https://doanhnghieptiepthi.vn/dot-nhapthe-gioi-noi-dung-18-tu-san-xuat-cua-gioi-tre-viet-quy-mo-ngay-cang-banhtruong-nhieu-tro-bien-thai-den-rung-minh-161211104144953776.htm

[3] Vuong, Q. H., et al. (2018). Cultural additivity: Behavioural insights from the interaction of Confucianism, Buddhism, and Taoism in folktales. Palgrave Communications, 4, 143.

[4] Vuong, Q. H., et al. (2020). On how religions could accidentally incite lies and violence: Folktales as a cultural transmitter. Palgrave Communications, 6, 82 .

[5] Do, L.A.T., Boonmongkon, P., Paek, S.C. et al. (2017). 'Hu Hong' (bad thing): parental perceptions of teenagers' sexuality in urban Vietnam. BMC Public Health 17, 226, DOI: $10.1186 / s 12889-017-4133-y$

[6] Khuat, T. H. (1998). Study on sexuality in Vietnam: the known and unknown issues. Population Council, Regional Office for South and East Asia Working Papers No. 11.

[7] Hong, K. T., Duong, L. B., \& Nguyen, N. (2010). Easy to joke about, but hard to talk about: Sexuality in contemporary Vietnam. Hanoi, Vietnam: World Publishing House.

[8] Vuong, Q. H., \& Napier, N. K. (2015). Acculturation and global mindsponge: an emerging market perspective. International Journal of Intercultural Relations, 49, 354-367.

[9] Vuong, Q. H. (2016). Global mindset as the integration of emerging socio-cultural values through mindsponge processes: A transition economy perspective. In J. 
Kuada (ed.) Global Mindsets: Exploration and Perspectives (pp. 109-126). London: Routledge.

[10] Vuong, Q. H. (2020). Reform retractions to make them more transparent. Nature, 582(7811), 149.

[11] Vuong, Q. H. (2019). Breaking barriers in publishing demands a proactive attitude. Nature Human Behaviour, 3(10), 1034.

[12] Vuong, Q. H. (2018). The (ir)rational consideration of the cost of science in transition economies. Nature Human Behaviour, 2(1), 5. 